\title{
Komunikasi Interpersonal Dosen dan Mahasiswa Skripsi dalam Membangun Motivasi melalui Media Pesan Instan
}

\author{
Felisitas Aurelia Virginia Dalentang ${ }^{1}$, Roswita Oktavianti ${ }^{2 *}$ \\ ${ }^{1}$ Fakultas Ilmu Komunikasi, Universitas Tarumanagara, Jakarta \\ Email: felisitasaureli@gmail.com \\ ${ }^{2}$ Fakultas Ilmu Komunikasi, Universitas Tarumanagara, Jakarta* \\ Email: roswitao@fikom.untar.ac.id
}

Masuk tanggal : 15-12-2021, revisi tanggal : 06-01-2022, diterima untuk diterbitkan tanggal : 06-01-2022

\begin{abstract}
The Covid-19 pandemic has caused the learning process to be carried out online, including thesis guidance. There is a change in interpersonal communication between lecturers and students, which previously took place face-to-face, turned into communication through instant messaging media, which affected the motivation of thesis students. This study aims to determine the process of interpersonal communication between lecturers and thesis students through instant messaging media in building motivation. The theory used in this research is the theory of communication, interpersonal communication, motivation, and instant messaging. The researcher uses the case study method, on interpersonal communication between lecturers and thesis students at Tarumanagara University, in West Jakarta. This research shows that interpersonal communication which is done online through message media, cannot build motivation, because through instant messaging media lecturers and thesis students cannot capture verbal and nonverbal reactions directly. Instant messages as a communication medium make it easier for lecturers and students to interact in real-time, but cause delays in students and can cause misunderstandings due to differences in message meaning.
\end{abstract}

Keyword: instant messaging, interpersonal communication, motivation

\begin{abstract}
Abstrak
Pandemi Covid-19 menyebabkan proses pembelajaran dilakukan secara daring, tidak terkecuali bimbingan skripsi. Adanya perubahan komunikasi interpersonal antara dosen dan mahasiswa, yang sebelumnya berlangsung secara tatap muka, berubah menjadi komunikasi melalui media pesan instan, yang berpengaruh kepada motivasi mahasiswa skripsi. Penelitian ini bertujuan untuk mengetahui proses komunikasi interpersonal antara dosen dan mahasiswa skripsi melalui media pesan instan dalam membangun motivasi. Teori yang digunakan dalam penelitian ini adalah teori komunikasi, komunikasi interpersonal, motivasi, dan pesan instan. Peneliti menggunakan metode studi kasus, pada komunikasi interpersonal dosen dan mahasiswa skripsi di Universitas Tarumanagara, di Jakarta Barat. Penelitian ini menunjukan bahwa komunikasi interpersonal yang dilakukan secara daring melalui media pesan, tidak dapat membangun motivasi, karena melalui media pesan instan dosen dan mahasiswa skripsi tidak dapat menangkap reaksi verbal dan nonverbal secara langsung. Pesan instan sebagai media komunikasi memudahkan dosen dan mahasiswa berinteraksi secara real-time, tetapi menyebabkan sifat menunda pada mahasiswa dan dapat menyebabkan kesalahpahaman akibat adanya perbedaan pemaknaan pesan.
\end{abstract}

Kata Kunci: komunikasi interpersonal, motivasi, pesan instan 


\section{Pendahuluan}

Selama pandemi Covid - 19, proses pembelajaran dilakukan secara daring, tidak terkecuali proses bimbingan skripsi. Dalam penyusunan skripsi, dosen dan mahasiswa melakukan komunikasi interpersonal, yaitu proses komunikasi yang menuntut hubungan antara komunikasi dengan perkembangan relasional, yang mempengaruhi sifat komunikasi antara pihak - pihak yang terlibat dalam hubungan tersebut. Menurut Joseph A DeVito, komunikasi interpersonal merupakan proses pengiriman dan penerimaan pesan antara dua orang dengan beberapa efek dan umpan balik seketika. Melalui komunikasi interpersonal, membantu individu dalam mengekspresikan perasaan, ide, dan pikiran (Liliweri, 2015).

Komunikasi interpersonal antara dosen dan mahasiswa skripsi merupakan faktor dalam membangun hubungan, sehingga diperlukan kemampuan komunikasi seperti menulis, membaca, berbicara, mendengarkan, dan berpikir yang baik. Jika hal tersebut telah terpenuhi, maka hubungan baik akan tercipta, dengan ditandai adanya sikap saling menghargai, sikap loyal, dan toleran antara mahasiswa dan dosen, sikap terbuka dan adanya keakraban (Abubakar, 2015).

Selama berlangsungnya bimbingan skripsi, mahasiswa membutuhkan motivasi dari dosen pembimbing. Menurut Oemar Hamalik, motivasi adalah perubahan energi pada seseorang yang ditandai dengan timbulnya afektif (perasaan) dan reaksi mencapai tujuan (Djamarah, 2011). Sementara, menurut Sadirman, motivasi memiliki tiga fungsi utama antara lain, (1) Mendorong manusia sebagai penggerak atau motor yang melepaskan energi. (2)Menentukan arah perbuatan, yakni kearah perbuatan yang dicapai. (3) Menyeleksi perbuatan, yakni menentukan perbuatan-perbuatan apa yang harus dikerjakan yang serasi guna mencapai tujuan, dengan menyisihkan perbuatan perbuatan yang tidak bermanfaat bagi tujuan (Sadirman, 1996). Melalui motivasi, mahasiswa mendapatkan dorongan dalam menyelesaikan skripsi.

Dalam penyampaiannya, komunikasi interpesonal antara dosen dan mahasiswa dilakukan melalui media sebagai alat dalam berkomunikasi. Komunikasi interpersonal bermedia merupakan komunikasi yang dilakukan melalui media untuk menggantikan interaksi langsung. Dalam penelitian ini, komunikasi bermedia yang digunakan adalah media pesan instan (instant messaging), yaitu sebuah teknologi internet yang mengizinkan para pengguna untuk mengirimkan pesan - pesan singkat secara langsung (real-time) menggunaan teks, gambar, dan pengiriman berkas kepada pengguna lainnya yang sedang terhubung melalui jaringan yang sama (Larasati, 2018).

Pesan instan, memiliki dua poin penting, pertama, penggunaan pesan instan memungkinkan adanya perbaikan dan penambahan dari aktivitas sosial. Kedua, pesan instan adalah penambahan dari alat atau media untuk dapat mengekspresikan perasaan. Penggambaran perasaan dalam pesan instan dapat dirasakan melalui penggunaan emotikon, suara dengan makna yang khas, manipulasi huruf, dan tema pesan instan yang dapat diubah sesuai dengan keinginan pengguna (Saleh, 2016). Dalam penelitian ini, media pesan instan yang digunakan adalah Line dan WhatsApp sebagai media komunikasi antara dosen dan mahasiswa skripsi, selama proses bimbingan.

Berdasarkan latar belakang tersebut, rumusan masalah dalam penelitian ini adalah bagaimana proses komunikasi interpersonal antara dosen dan mahasiswa skripsi dalam membangun motivasi melalui media pesan instan? Penelitian ini bertujuan untuk mengetahui proses komunikasi interpersonal antara dosen dan mahasiswa skripsi dalam membangun motivasi melalui media pesan instan. 
Felisitas Aurelia Virginia Dalentang, Roswita Oktavianti: Komunikasi Interpersonal Dosen dan Mahasiswa Skripsi dalam Membangun Motivasi melalui Media Pesan Instan

Penelitian ini bermanfaat secara akademis bagi pengembangan ilmu komunikasi terutama komunikasi interpersonal. Selain itu, hasil penelitian ini berguna untuk dosen sebagai tenaga pendidik, dalam membangun motivasi mahasiswa skripsi. Serta berguna untuk mahasiswa, dalam membangun hubungan baik dengan dosen melalui pesan instan.

\section{Metode Penelitian}

Peneliti menggunakan pendekatan penelitian kualitatif, menurut Cresswell penelitian kualitatif bertujuan untuk menggali serta memahami suatu informasi dengan mengajukan pertanyaan - pertanyaan terhadap subjek penelitan bersifat umum namun dengan jangkauan yang luas. Koentjaraningrat mendefinisikan penelitian kualitatif sebagai penelitian di bidang ilmu kemanusiaan dengan aktivitas dalam mengumpulkan, mengkelaskan, menganalisis, dan menapsirkan fakta - fakta serta hubungan - hubungan antara fakta, alam, masyarakat, kelakuan, dan rohani manusia guna menemukan prinsip pengetahuan dan metode baru (Suwendra, 2018). Pendekatan penelitian kualitatif dalam penelitian ini, bertujuan untuk menggali pengalaman komunikasi interpersonal antara dosen dan mahasiswa skripsi dalam membangun motivasi melalui media pesan instan.

Metode penelitian yang digunakan adalah studi kasus. Studi kasus merupakan uraian dan penjelasan komprehensif mengenai berbagai aspek seorang individu, kelompok, organisasi, program, dan situasi sosial (Suwendra, 2018). Melalui metode studi kasus, peneliti akan menjabarkan komunikasi interpersonal antara dosen dan mahasiswa skripsi di Universitas Tarumanagara (Untar). Untar dipilih menjadi lokasi penelitian karena mendapatkan peringkat peringkat 601+ QS Asia, dan peringkat 30 khusus PTN/PTS di Indonesia.

Subyek dalam penelitian ini adalah dosen pembimbing, dan mahasiswa skripsi, Universitas Tarumanagara. Kemudian, obyek dari penelitian ini adalah komunikasi interpersonal dalam membangun motivasi melalui media pesan instan. Obyek menarik untuk diteliti karena adanya kondisi pandemi Covid-19, yang menyebabkan proses komunikasi interpersonal dalam bimbingan skripsi yang sebelumnya dilakukan secara tatap muka, berubah secara daring melalui pesan instan.

Metode pengumpulan data yang dilakukan, melalui wawancara, observasi, dan studi kepustakaan. Narasumber dalam wawancara ini, yaitu Bapak Erik Wiyaja, S.Psi. M.Si. dosen Fakultas Psikologi Untar, dan ibu Wulan Purnamasari, S.Ikom., M.Si. dosen Fakultas Ilmu Komunikasi (Fikom) Untar dan dua mahasiswa skripsi, Fellisia mahasiswa Fakultas Psikologi Untar, dan Stephanie Violita, mahasiswa Fikom Untar.

Kriteria dalam wawancara ini, dosen Universitas Tarumanagara yang bertugas sebagai dosen pembimbing skripsi, dan aktif dalam menggunakan media pesan instan. Kriteria mahasiswa, yaitu mahasiswa skripsi Universitas Tarumanagara angkatan 2018, memiliki keterlibatan dan aktif dalam proses bimbingan skripsi dengan dosen melalui pesan instan.

Dalam penelitian ini, peneliti melakukan observasi melalui tangkapan layar chat (ruang obrolan) antara mahasiswa dan dosen melalui pesan instan. Peneliti melakukan pengumpulan data dengan studi kepustakaan melalui buku - buku, literatur, catatan, dan laporan yang berhubungan dengan masalah yang akan dipecahkan. Studi kepustakaan digunakan sebagai pedoman dalam membandingkan teori dan realita yang terjadi di lapangan (Veronica, 2020). 
Peneliti menggunakan teknik triangulasi, yaitu penggunaan beberapa metode dalam sebuah penelitian. Triangulasi dibutuhkan karena setiap metode pengumpulan data memiliki kelemahan dan keunggulannya sendiri (Widjaja, 2018). Peneliti menggunakan teknik triangulasi sumber dengan membandingkan hasil wawancara informan, dan observasi pada pesan instan antara dosen dan mahasiswa, serta konsep yang didapatkan dari studi pustaka.

\section{Hasil Penemuan dan Diskusi}

\section{Komunikasi Interpersonal antara Dosen dan Mahasiswa Skripsi secara Daring}

Dengan adanya pandemi Covid-19, komunikasi interpersonal antara dosen dan mahasiswa yang sebelumnya berlangsung secara tatap muka, berubah menjadi komunikasi secara daring. Aplikasi WhatsApp, dan Line menjadi media komunikasi antara dosen dan mahasiswa skripsi. Fitur ruang obrolan personal digunakan dalam membagikan informasi, dan melakukan konsultasi dosen dan mahasiswa skripsi.

Dalam komunikasi interpersonal, terdapat keterlibatan, yaitu tahap pengenalan jauh, dan pengungkapan diri kepada orang lain (dosen dan mahasiswa skripsi). Sikap kooperatif dan keterlibatan mahasiswa selama proses bimbingan diperlukan agar dosen mengetahui kendala yang dialami mahasiswa, dan dapat membantu dalam menyelesaikan masalah.

Dalam membangun keakraban dengan mahasiswa informan pertama, dan kedua selaku dosen menyampaikan budaya bimbingan terlebih dahulu seperti pengunaan bahasa yang tidak formal dan diselingi dengan humor. Usaha yang dilakukan ini berdampak pada suasana bimbingan skripsi bersama mahasiswa.

"Biasanya saya, karena saya tahu mahasiswa itu tidak eee.. apa perlu yang formal -formal, maka mahasiswa kalo manggil saya itu ko. Dari awal ketika mereka kenal, jaman sebelum pandemi panggil saya ko Erik aja ya, gausah panggil pak! Walaupun saya udah bapak - bapak sekarang, tapi panggil saya ko Erik. Itu adalah cara saya supaya bangun komunikasi lebih lancar secara psikologis kan mereka anggep saya kakak gitu ya.. nah itu yang pertama. Yang kedua, saya biasa ngobrol itu ngalir aja, tidak pernah pake kata-kata formal, teknis macem - macem belibet, gitu ya, diselingi dengan humor gitu ya. Saya kalaupun eee.. apa.. bimbingan segala macem, banyak ga formalnya yang penting mereka ngerti. Saya tidak perlu seperti seolah - olah terlihat pintar trus saya menggunakan bahasa - bahasa teknis. Gausah, ga guna juga buat mahasiswa hahaha." (Bapak Erik - Dosen Fakultas Psikologi Universitas Tarumanagara).

"Kalau masalahh... kenyamanan sih, gue bingung juga yaa, pokoknya dari awal gue udah jelaskan, budaya bimbingan gue seperti ini. Biasanya, gue ngomong pake gue - elu, kalian mau chat diatas jam kerja silahkan, tapi tolong jangan telpon, karena gue gapernah angkat telepon. Disini tuh udah gue jelasin dari awal, dan gue mau nanti semua pakai Mandeley itu juga sudah gue jelaskan dari awal. Dan seandainya gabisa, karena terkendala masalah, eee.. misalnya hardwarenya tidak mendukung, nanti kita cari jalan keluarnya. Intinya sih... eeee.... lebih fleksibel aja gitu ya. Dan seandainya mereka mau cari tema penelitian juga eee... kalo dari gue sendiri dari kalian. Jadi gue ga mau menentukan, kagak kalo anak bimbingan gue temanya harus begini, gitu. 
Felisitas Aurelia Virginia Dalentang, Roswita Oktavianti: Komunikasi Interpersonal Dosen dan Mahasiswa Skripsi dalam Membangun Motivasi melalui Media Pesan Instan

Gaada itu gaada. Kalo gue, lakukanlah penelitian yang kalian sukai, dekat, dan kalian merasa mampu untuk menyelesaikan." (Ibu Wulan - Dosen Fakultas Ilmu Komunikasi Universitas Tarumanagara).

Pernyataan tersebut, di dukung oleh informan ketiga dan keempat, selaku mahasiswa. Penggunaan bahasa informal diselingi dengan humor membuat mahasiswa tidak merasa terbebani, tegang, ataupun suasana takut. Selain itu, budaya bimbingan yang disampaikan pada awal pertemuan, membuat proses bimbingan skripsi berjalan secara efektif.

"Ok, kalo suasananya itu awal masuk ko Erik sudah hahahaha hihihihi gitu aja, jadi kayak setiap skiripsi itu bawaannya nggak terasa beban gitu, jadi yaudah bimbingan nih sama dosen, yaudah bimbingan, karena dosenya selalu ee dibawain canda sama dibawain santai, jadi ketika bimbingan, gaada suasana tegang ataupun, eee suasana takut." (Fellisia - Mahasiswa Skripsi Fakultas Psikologi Universitas Tarumanagara).

"Efektif sih, soalnya hmmm berurutan ga bertele - tele juga. Kalo kita sistemnya sih ini, satu kelas kan kita 18, jadi dibagi dua jadi sembilan sembilan, satu orang satu kali sih."(Stephanie Violita - Mahasiswa Skripsi Fakultas Ilmu Komunikasi Universitas Tarumanagara).

Peneliti menemukan bahwa penelitian terdahulu oleh Putra, Heri Rahmatsyah (2019) memiliki perbedaan situasi, komunikasi interpersonal yang berlangsung secara tatap muka, yang memungkinkan dosen dan mahasiswa skripsi berkomunikasi secara verbal dan nonverbal, sehingga dapat melihat reaksi dari lawan bicara.

Meskipun komunikasi interpersonal antara dosen dan mahasiswa skripsi dilakukan melalui media pesan instan, sikap keterbukaan, sikap keterlibatan, dan sikap keakraban dosen dan mahasiswa skripsi melalui media pesan instan berjalan dengan baik.

\section{Relasi Dosen dengan Mahasiswa dalam Meningkatkan Kualitas Skripsi}

Ada beberapa faktor yang menentukan keberhasilan bimbingan skripsi, yaitu pembimbing, mahasiswa, kerjasama antara pembimbing dan mahasiswa, dan masalah yang dibahas (Siswoharjono, 1991). Dosen pembimbing memiliki kemampuan dalam penguasaan materi terhadap masalah yang diteliti, latar belakang studi dan kemampuan dalam membangun komunikasi.

Dalam wawancara, informan pertama akan membantu meningkatkan kualitas skripsi mahasiswa dengan memberikan referensi jurnal sesuai dengan penelitian mahasiswa. Selain memberikan referensi jurnal, Ia mengajarkan cara cepat membaca jurnal. Berbeda dengan informan pertama, informan kedua memberikan tutorial Mandeley, dan mengarahkan mahasiswa untuk mencari sumber referensi yang tepat.

"Biasanya, saya kasih bahan bacaan, kemudian mereka baca, dan saya kasih tau bagaimana cara baca cepat, gitu ya. Yang selama ini terjadikan ada tuh banyak orang yang baca itu, dari atas ke bawah semuanya dibaca gitu, padahalkan yang perlu dibaca itukan inti - intinya saja, misalnya kita baca jurnal. Sesungguhnya, kalau mau baca jurnal cepat, kan bisa dari abstrak, nah dari abstrak itu dia sudah kelihatan mau ngomong apa. Nah kemudian setelah 
abstrak, itu kita bisa baca hasilnya gitu. Nah, itu aja sebenarnya pokoknya, jadi judul abstrak, sama hasil gitu, baru gitu kita setelah eee.. hasilnya udah, teorinya yang dipake apa, nah kita baca. Nah saya ajarin baca cepat caranya seperti itu. Nah jadi saya lebih menekankan kepada mahasiswa skripsi itu bacanya jurnal, karena dari jurnal itu kita sudah tau, ini teori yang berbasis penelitian. Inilah jurnal, sudah dipublikasi, artinya kan pasti sudah dibaca oleh banyak orang, gitulah ya. Karena dari jurnal kita tau, penelitian terdahulu seperti apa, kemudian kekurangannya seperti apa, gitukan ya. Ada kekurangannya kan pasti, ada limitation-nya. Nah kita masuk ke limitationnya itu untuk melakukan penelitian lanjutan, dan memiliki dasar untuk bergerak." (Bapak Erik - Dosen Fakultas Psikologi Universitas Tarumanagara).

"Kalo bimbingan gue, satu gue suruh pake Mandeley. Jadi diawal-awal eee... bimbingan itu, setelah tema udah dapet semua, habis itu gue biasanya ada tutorial Mandeley dulu sama mereka. Jadi mereka tau bagaimana memakai Mandeley, dan bagaimana cara mencari sumber referensi yang benar, jadi kalau nyari tuh harus dari Google Scholar, jangan pakai Blogspot jadi seperti itu. Biasanya kalau diakhir sidang nanti itu ada tutorial Mandeley sekali lagi, karena biasanya ya, pengalaman gue kalau mahasiswa pakai Mandeley ga paham kalau metadata Mandeley itu tuh, harus di edit. Jadi daripada nanti jelek ya, berantakan gue sebel ngeliatinnya, jadi mendingan kita tutorial sekali lagi, cuman buat edit." (Ibu Wulan - Dosen Fakultas Ilmu Komunikasi Universitas Tarumanagara).

Selain membantu meningkatkan kualitas skripsi, dosen turut serta membantu mahasiswa skripsi yang mengalami miss-komunikasi. Mahasiswa yang sedang mengalami miss-komunikasi dengan dosen dapat mengatakannya secara langsung, agar dosen mengetahui kesulitan yang dialami.

Hasil wawancara ini memiliki persamaan pada penelitian (Ristianti, 2019) terletak pada hubungan interpersonal, sikap loyalitas dan toleransi antara mahasiswa dan dosen berjalan dengan baik. Perbedaann penelitian ini terletak pada situasi komunikasi interpersonal yang dilakukan secara tatap muka.

\section{Dosen Tidak Dapat Membangun Motivasi Mahasiswa dalam Bimbingan Skripsi melalui Media Pesan Instan}

Oemar Hamalik mendefinisikan motivasi sebagai suatu perubahan energi di dalam pribadi seseorang yang ditandai dengan timbulnya afektif (perasaan) dan reaksi mencapai tujuan (Djamarah, 2011).

Sadirman menyebutkan bahwa motivasi memiliki tiga fungsi, pertama, mendorong manusia sebagai penggerak atau motor yang melepaskan energi. Kedua, menentukan arah perbuatan. Ketiga, menyeleksi perbuatan yaitu menentukan perbuatan - perbuatan apa yang harus dikerjakan yang serasi guna mencapai tujuan, dengan menyisihkan perbuatan - perbuatan yang tidak bermanfaat bagi tujuan.

Dalam memotivasi mahasiswa skripsi, berdasarkan wawancara informan pertama dan kedua, dosen berusaha untuk menghargai dan memahami skripsi atau tulisan yang sudah dibuat mahasiswa. Jika mahasiswa mengalami kesulitan, dosen akan membantu dalam menyelesaikan masalah. 
Felisitas Aurelia Virginia Dalentang, Roswita Oktavianti: Komunikasi Interpersonal Dosen dan Mahasiswa Skripsi dalam Membangun Motivasi melalui Media Pesan Instan

"Motivasi yang berusaha saya bangun misalnya mahasiswa kirim paper mahasiswa bab 1,2,3 ko Erik maaf ya ko ini masih bolong - bolong. Saya bilang, gapapa, namanya juga baru nulis, saya tambahin masukan segala macem, nah kamu cari nanti kamu parafrase. Ya kira - kira seperti itu."(Bapak Erik-Dosen Fakultas Psikologi Universitas Tarumanagara).

"Motivasi... eee.... kalo di gue sih membangun motivasi itu, biasanya sih gue cuman ngasih gini ya, intinya kalau kalian mau menyelesaikan dalam satu semester, diselesaikan saja gitu, dan jangan mengejar kesempurnaan lebih. Yang namanya penelitian, skripsi kan kalian baru pertama kali. Hasilnya, walaupun kalian baca 2 - 3 tahun lagi, kalian akan merasa apa yang dulu gue bikinn. jadi sekarang targetnya adalah selesai dulu. Dan jangan mikirin yang lain - lain, fokus dulu aja."(Ibu Wulan - Dosen Fakultas Ilmu Komunikasi Universitas Tarumanagara).

Informan ketiga, dan keempat, selaku mahasiswa menyatakan benar adanya pemberian motivasi oleh dosen untuk menyelesaikan skripsi, akan tetapi kalimat motivasi tersebut tidak membuatnnya terpacu untuk menyelesaikan skripsi. Namun, mampu menurunkan ketengangan saat seminar proposal (sempro).

"Hmmm, terpacu... kurang sih kalo dari saya ya, tapi kayak merasa lega aja, jadi ga terlalu tegang sama sempro, gitu aja sih.” (Fellisia Mahasiswa Skripsi Fakultas Psikologi Universitas Tarumanagara).

"Untuk terpacu, hmm dari aku pribadi enggak sih biasa ajaa, mungkin karena dari Line kali ya, jadi aku gabisa liat bahasa tubuh atau suaranya ci Wulan."(Stephanie Violita - Mahasiswa Skripsi Fakultas Ilmu Komunikasi Universitas Tarumanagara).

Hal ini terjadi karena pada hakikatnya, komunikasi interpersonal berlangsung secara tatap muka, dan berkomunikasi secara verbal dan nonverbal. Sehingga ketika berkomunikasi melalui media pesan instan, dosen dan mahasiswa skripsi tidak dapat menangkap reaksi verbal dan nonverbal secara langsung, maka motivasi yang diberikan dosen kepada mahasiswa skripsi melalui media pesan instan tidak dapat diterima dengan baik.

Hasil temuan ini berbeda dengan penelitian sebelumnya yang dilakukan oleh Pratama, Anggraini, dan Hermano (2017), penelitian ini meneliti tentang komunikasi interpersonal dosen dan mahasiswa skripsi secara langsung memiliki pengaruh yang kuat, sehingga meningkatkan motivasi mahasiswa.

\section{Pesan Instan Sebagai Media Komunikasi Interpersonal antara Dosen dan Mahasiswa}

Komunikasi interpersonal bermedia merupakan komunikasi yang dilakukan melalui media dalam menggantikan interaksi langsung (Larasati, 2018). Media yang digunakan dalam berkomunikasi antara dosen dan mahasiswa, adalah media pesan instan yaitu, teknologi yang berfungsi untuk mengirimkan pesan singkat secara langsung, dalam menggunakan teks, gambar, dan pengiriman berkas kepada pengguna lainnya yang sedang terhubung ke jaringan yang sama. 
Berdasarkan hasil wawancara dengan informan pertama dan kedua, serta melalui tangkapan layar ruang obrolan pribadi (personal chat) antara dosen dan mahasiswa, diketahui bahwa tidak adanya aturan dalam waktu maupun penggunaan emotikon/emoji dalam pengiriman pesan melalui media pesan instan.

"Wah, ga usah sih udah gede kan, atau misalnya ada sih dosen lain yang gamau di chat malem - malem.tapi kalo saya, mahasiswa nge-chat malem malem saya oke - oke aja tuh, selama saya masih on ya saya jawab. Dan bahasanya, bahasa mahasiswa ya enggak gimana - gimana banget. Jadi yaudah. Nah kalo misalnya saya jawabnya lama, berarti saya ada something. Misalnya, saya rapat atau hp saya lagi di rebut sama anak untuk nonton youtube. Tapi saya pasti bales. Sampe chat hari minggu pun ada, gapapa, gaada masalah. kalo buat aturan ya, tetap anda harus menganggap saya dosen, bukan teman segala macem." (Bapak Erik - Dosen Fakultas Psikologi Universitas Tarumanagara).

"Gak ada, kalo gue terserah ya, dia mau pake emotikon, mau pake stiker. Dia mau nge-line jam 10. Intinya kalau gue masih bangun gue bales, tapi kalau gue udah tidur yaudah lu tunggu aja sampai besok pagi." (Ibu Wulan-Dosen Fakultas Ilmu Komunikasi Universitas Tarumanagara).

Melalui hasil observasi pada tangkapan layar personal chat antara dosen dan mahasiswa skripsi, diketahui bahwa penggunaan emotikon pada pesan instan yang dikirimkan melalui media pesan instan berfungsi sebagai penggambaran perasaan ataupun reaksi atas percakapan yang dilakukan antara dosen dan mahasiswa skripsi melalui media pesan instan (Saleh, 2016).

Pesan instan memiliki kelebihan dan kekurangan, sebagai media komunikasi antara dosen dan mahasiswa skripsi. Berdasarkan hasil wawancara, pesan instan memiliki kelebihan, yaitu proses bimbingan dapat dilakukan kapanpun dan dimanapun. Selain itu, media pesan instan membantu dosen dan mahasiswa dalam berinteraksi secara langsung atau real-time.

"Kekurangannya sudah pasti, manusia itu kan prinsipnya mahluk sosial. Mahluk sosial itu eeee.... salah satu cirinya, mau ketemu fisik. Cuma gimana ya pandemi ini ga bisa ditawar - tawar. Jadi itu yang dikorbankan, ketemu langsung itu jauh lebih enak, karena ketemu orangnya kita bisa lihat, ketika lagi komunikasi dan segala macem. Tapi, kelebihannya juga banyak, dimanapun dan kapanpun kita bisa bimbingan. Saya tidak mewajibkan mahasiswa buka kamera, karena kita harus meringankan beban mahasiswa, dalam artian misalnya dirumahnya ada apa gitu segala macem tutup kamera dulu ya gapapa."(Bapak Erik - Dosen Fakultas Psikologi Universitas Tarumanagara).

"Kalo kelebihannya itu, satu praktis, kapan dan dimana aja gue bisa langsung chat. Kayak misalnya dulu harus ke kampus belum tentu jadwalnya sama, kalo ini tetep bisa terkoneksi, intinya. Selama masih ada paket data it's okay, ya cuman kekurangannya itu seperti yang gue bilang, kata - kata itu kan punya keterbatasan, dan karena dia tidak melihat, dan belum tentu dia paham maksud gue apa, gue maksudnya A dia nangkepnya separuhnya A. Jadi beberapa hal 
Felisitas Aurelia Virginia Dalentang, Roswita Oktavianti: Komunikasi Interpersonal Dosen dan Mahasiswa Skripsi dalam Membangun Motivasi melalui Media Pesan Instan

yang menurut gue, akan missed kalo kita jelasin pake chat. Kayak misalnya, ngomongin kuantitatif gitu ya, nah itu kalo gue jelasin di chat kan kayaknya panjang $x$ lebar $x$ tinggi, capek ya, paling keterbatasannya sih itu gue." (Ibu Wulan - Dosen Fakultas Ilmu Komunikasi Universitas Tarumanagara).

Pesan instan membuat adanya perbedaan pemaknaan pesan yang diterima oleh mahasiswa, sehingga dapat menyebabkan miss-komunikasi. Selain itu, dari hasil wawancara ditemukan bahwa proses bimbingan skripsi melalui media pesan instan, membentuk sifat menunda pada mahasiswa dalam mengerjakan skripsi, terlebih dosen tidak memberikan tenggat waktu dalam proses bimbingan.

"Kalo kelebihannya, cepet sih, kayak kalo kita chat dibales gitu pertanyaan kita, Cuma kalo misalnya kekurangan menurut saya, hmmm, bisa ditunda tunda gitu, apalagi, ko Erik ini ga ada waktu yang ditentukan seperti yang tadi kita bahas. Jadi kadang, udahlah masih bisa besok di chat, gitu - gitu sih."(Fellisia - Mahasiswa Skripsi Fakultas Psikologi Universitas Tarumanagara).

"Eee... kelebihannya, pasti lebih mudah dihubungi, kalo offline kan kita harus nyari dosenya, gitu ya kayak kalo misalnya dia lagi ngajar kita tungguin, kayak gitu - gitu. Kekurangannya, suka miss-komunikasi kadang - kadang, karena kalo pesan instan menggunakan tulisan, nah kita nangkepnya apa dosen maksudnya apa, karena gaada nadanya juga." (Stephanie Violita Mahasiswa Skripsi Fakultas Ilmu Komunikasi Universitas Tarumanagara).

\section{Simpulan}

Proses bimbingan skripsi melalui media pesan instan dimulai dengan dosen memberikan aturan selama proses bimbingan skripsi, seperti penggunaan bahasa informal yang diselingi dengan humor, serta tidak adanya aturan dalam waktu dan penggunaan emotikon/emoji dalam mengirim pesan kepada dosen. Selain itu, adanya sikap keterlibatan antara dosen dan mahasiswa skripsi seperti adanya diskusi dalam mengingatkan jadwal bimbingan skripsi, megingatkan jadwal pengumpulan skripsi.

Meskipun terjadi komunikasi yang intensif melalui media pesan instan, penelitian menunjukkan bahwa mahasiswa tidak menganggap adanya motivasi di dalam komunikasi tersebut. Hal ini disebabkan karena komunikasi interpersonal melalui media pesan instan, membuat dosen dan mahasiswa skripsi tidak dapat menangkap reaksi verbal dan non-verbal secara langsung, sehingga motivasi yang diberikan oleh dosen tidak dapat diterima dengan baik.

Pesan instan sebagai media komunikasi antara dosen dan mahasiswa memiliki kelebihan, yaitu memudahkan dosen dan mahasiswa untuk berinteraksi, karena berlangsung secara real-time. Kekurangannya, pesan instan menyebabkan sifat menunda pada mahasiswa dan dapat menyebabkan miss-komunikasi akibat adanya perbedaan pemaknaan pesan.

\section{Ucapan Terima Kasih}

Peneliti ingin mengucapkan terima kasih kepada Fakultas Ilmu Komunikasi Universitas Tarumanagara, narasumber, serta semua pihak yang turut membantu peneliti sehingga penelitian ini dapat diselesaikan. 


\section{Daftar Pustaka}

Abubakar, F. (2015, April 1). Pengaruh Komunikasi Interpersonal antara Dosen dan Mahasiswa Terhadap Motivasi Belajar dan Prestasi Akademik Mahasiswa. Jurnal Pekommas, 18, 53-62.

DeVito, J. A. (2011). Komunikasi Antarmanusia. Tangerang Selatan: Karisma Publishing Group.

Djamarah, S. (2011). Psikologi Belajar. Jakarta: Rineka Cipta.

Larasati, R. P. (2018). Studi Deskriptif Kualitatif Proses Komunikasi Interpersonal Bermedia baru pada Penyandang Difabel Netra melalui Platform Pesan Instan di Komunitas Braille'ant Yogyakarta. Skripsi, 2-209.

Liliweri, A. (2015). Komunikasi Antarpersonal. Jakarta: Prenamedia Group.

Sadirman, A. (1996). Interaksi dan Motivasi Belajar Mengajar. Jakarta: PT.Raja Grafindo Persada.

Saleh, D. (2016). Penggunaan Instant Messaging Pada Keintiman Hubungan Pacaran Jarak Jauh. Bandung: Universitas Padjadjaran.

Siswoharjono. (1991). Perspektif Bimbingan Konseling dan Penerapannya di Berbagai Institusi. Semarang : Satya Wacana .

Veronica. (2020). Strategi Marketing Public Relations Dalam Meningkatkan Brand Awareness Atourin (Studi Melalui Event Virtual Tour Pada Masa Pandemi Covid-19). Fakultas Ilmu Komunikasi Universitas Tarumanagara, 24.

Widjaja, R. (2018). Strategi Keberlangsungan Usaha Kedai Kopi Es Tak Kie di Gang Gloria Glodok Jakarta Barat. Culinary Business Department Fakultas Pariwisata. 